\title{
PENERAPAN MODEL PERMAINAN CIRCUIT TERHADAP PEMBELAJARAN LOMPAT JAUH GAYA JONGKOK PADA SI SWA KELAS VII SMP NEGERI 2 ELLA HILIR
}

\author{
Jeki $^{1}$, Suyatmin ${ }^{2}$, Indria Susilawati ${ }^{3}$ \\ ${ }^{1}$ Mahasiswa Program Studi Penjaskesrek \\ ${ }^{2}$ Dosen STKIP Melawi \\ ${ }^{3}$ Dosen STKIP Melawi \\ Jln. RSUD Melawi km. 04 Nanga Pinoh Kabupaten Melawi \\ Email: inyomanjeckys@gmail.com, suyatminuny@gmail.com, \\ smile_indria@yahoo.com
}

\begin{abstract}
Abstrack: This study aims to determine the effect of the circuit activity model of the game on squat style long jump learning in grade VII (seven) junior high school students Ella Hilir.

This type of research is quasi-experimental with one group pretest posttest design. The method used in this research is the circuit activity model game method. The results of the pretest and posttest $>$ of t table have a significance value of 0.00 or smaller than 0.05 which means that there are differences in the learning of the basic technique of long jump squat style on students between before and after treatment. In the table one sample test looks average for before getting treatment $=57.91$ and after getting treatment $=82.08$. This means that the average value before receiving treatment is lower than after receiving treatment. With an inrease in the average value of $=24,17$.Based on the results of the analysis shows that "There is a significant influence of the method of the model of circuit activity games on squat style long jump learning in Ella Hilir 2 Public Middle School.
\end{abstract}

Keywords: Model Method of Activity Circuit Games, Learning outcomes of the basic techniques of long jump squat style.

Abstrak: Penelitian ini bertujuan untuk mengetahui pengaruh model permainan aktivtas circuit terhadap pembelajaran lompat jauh gaya jongkok pada siswa kelas VII (tujuh) SMP Negeri 2 Ella Hilir. Jenis penelitian ini adalah eksperimen semu dengan rancangan one group pretest posttest design. Metode yang di gunakan dalam penelitian ini adalah metode model permainan aktivitas circuit. Hasil pretest dan posttest dari t tabel terdapat nilai signifikasinya sebesar 0,00 atau lebih kecil dari 0,05 artinya menunjukan bahwa ada perbedaan pada pembelajaran teknik dasar lompat jauh gaya jongkok pada siswa antara sebelum dan sesudah mendapat perlakuan. Pada tabel one sample test terlihat nilai rata-rata untuk sebelum mendapat perlakuan $=57,91$ dan sesudah mendapat perlakuan $=82,08$. Artinya nilai rata-rata sebelum mendapat perlakuan lebih rendah dari sesudah mendapat perlakuan. Dengan peningkatan nilai rata-ratanya yaitu sebesar $=$ 24, 17.Berdasarkan hasil analisis menunjukkan bahwa Terdapat pengaruh yang signifikan dari metode model permainan aktivitas circuit terhadap pembelajaran lompat jauh gaya jongkok di sekolah SMP Negeri 2 Ella Hilir.

Kata kunci: Metode Model Permainan Aktivitas Circuit, Hasil pembelajaran teknik dasar lompat jauh gaya jongkok. 


\section{Jurnal Pendidikan Jasmani Kesehatan dan Rekreasi (Penjaskesrek) \\ Volume 8, Nomor 1, Januari 2021}

$\mathrm{P}$ endidikan jasmani sebagai salah satu mata pelajaran di sekolah memiliki peran yang relatif besar terhadap perkembangan perilaku siswa seperti aspek kognitif, afektif, dan khususnya aspek psikomotorik. Rusli Lutan (2000:6) menjelaskan bahwa: “istilah pendidikan jasmani (pshysical education) merupakan suatu kegiatan yang bersifat mendidik". Pendidikan jasmani memberikan dasar-dasar pengetahuan dan keterampilan dalam bidang olahraga dan kesehatan, juga memberikan peluang bagi siswa untuk mengembangkan dirinya agar mencapai suatu prestasi dalam berbagai cabang olahraga.

Atletik merupakan sarana untuk pendidikan jasmani dalam upaya meningkatkan daya tahan, kekuatan, kecepatan, kelincahan dan lain sebagainya, selain untuk sarana pendidikan juga sebagai sarana penelitian para ilmuan (Djumidar, 2001:13). Pembelajaran lompat jauh adalah salah satu materi pelajaran olahraga yang sering dilakukan oleh siswa di sekolah sesuai dengan prosedur yang diajarkan oleh guru PJOK. Lompat jauh adalah suatu aktivitas dalam atletik dengan gerakan yang dilakukan dalam lompatan untuk mencapai lompatan yang sejauhjauhnya. Gerakan lompat jauh memperpadukan kecepatan, kekuatan, kelenturan, daya tahan dan ketepatan. (Aminuddin, 2010:17) lompat jauh merupakan salah satu nomor yang di pertandingkan pada cabang olahraga atletik. Di sekolah-sekolah olahraga ini telah menjadi bagian materi dari kurikulum pendidikan jasmani yang harus dipelajari. Tujuan dari lompat jauh adalah melompat sejauh-jauhnya dengan tahapan awalan, tolakan, melayang dan mendarat. (Djumidar, 2006: 13).

Lompat jauh adalah olahraga yang sukar dicapai oleh siswa karena harus mampu menguasai teknik dasar dari olahraga tersebut, dalam olahraga lompat jauh harus mampu memiliki nilai rata-rata yang harus ditempuh oleh siswa. Lompat jauh memiliki beberapa teknik dasar yang harus dikuasai seperti tahap awalan, tumpuan (tolakan), melayang diudara dan mendarat. Teknik dasar tersebut memerlukan koordinasi anggota tubuh, contohnya berlari lalu melakukan tumpuan(tolakan) kemudian 


\section{Jurnal Pendidikan Jasmani Kesehatan dan Rekreasi (Penjaskesrek) \\ Volume 8, Nomor 1, Januari 2021}

dilajutkan dengan sikap melayang di udara dan yang terakhir melakukanpendaratan, sebelum menguasai gerak dasar tersebut siswa harus bisa memahami cara melakukan gerakan. Apabila siswa sudah memahami secara otomatis siswa bisa melakukan gerak tersebut dengan benar, tetapi bagi seorang siswa tidak mudah untuk melakukan lompat jauh seperti berlari, tumpuan (tolakan), melayang di udara dan mendarat sesuai dengan indikator yang telah ditentukan didalam olahraga lompat jauh.

Berdasarkan hasil observasi yang dilakukan oleh penulis, yang dilaksanakan pada tanggal 19 Juli 2019 tempatnya di SMP Negeri 2 Ella Hilir dalam pembelajaran pendidikan jasmani olahraga dan kesehatan (PJOK) khususnya pada pembelajaran lompat jauh gaya jongkok. Pada saat melakukan lompat jauh gaya jongkok siswa menginginkan pembelajaran yang cepat tanpa ingin mengetahui tentang peraturan dan teknik dasar yang ada dalam lompat jauh gaya jongkok, siswa tidak tertarik pada proses belajar mengajar dalam pembelajaran lompat jauh gaya jongkok karena siswa lebih menyukai pembelajaran olahraga permainan bola kaki dan bola voli, siswa kurang mampu melakukan tahapan pembelajaran teknik dasar lompat jauh karena siswa tidak memahami tentang teknik dasar dalam pembelajaran lompat jauh, siswa tidak mendengarkan arahan dari gurupada saat melakukan tahapan pembelajaran teknik dasar lompat jauh khususnya lompat jauh gaya jongkok karena siswa asik berbicara dengan teman ketika guru memberikan arahan sehingga kondisi ini bisa membuat proses belajar mengajar tidak efektif. Dengan demikian penulis ingin melihat suatu perkembangan pembelajaran lompat jauh khususnya pada pembelajaran lompat jauh gaya jongkok siswa dengan baik yang sesuai dengan harapan penulis. Penulis melihat beberapa kenyataan yang terjadi tidak sesuai dengan harapan, karena siswa tidak tertarik pada proses pembelajarannya dibandingkan dengan olahraga lompat jauh secara langsung sehingga siswa kurang mampu untuk mempraktekkan teknik dasar lompat jauh khususnya dalam pembelajaran lompat jauh gaya jongkok. 


\section{Jurnal Pendidikan Jasmani Kesehatan dan Rekreasi (Penjaskesrek) \\ Volume 8, Nomor 1, Januari 2021}

Melihat permasalahan tersebut Peneliti ingin memberikan solusi yaitu dengan penerapan model permainan aktivitas circuit. Penerapan model permainan aktivitas circuit yaitu model permainan menggunakan pos dengan menggunakan media ban bekas, tali rapia dan kardus diletakan sesuai dengan pos yang sudah ditentukan dan durasi waktu sesuai dengan kegiatan di setiap posnya. Model permainan aktivitas circuit merupakan suatu permainan yang bertujuan untuk memberikan penyesuaian dan koordinasi siswa untuk melakukan gerakan awalan, tumpuan (tolakan), melayang dan mendarat di bak pasir pada materi lompat jauh. Adapun kelebihan dari model permainan aktivitas circuit ini yaitu suatu kegiatan yang tidak monoton sehingga siswa tidak bosan untuk melakukan kegiatan tersebut karena di setiap pos kegiatanya berbeda-beda (bervariasi) dan kemampuan fisik siswa juga bisa bertambah karena sering mempraktekkan lari dan melompat saat melakukan aktivitas circuit.

\section{METODE PENELITIAN}

Sugiyono, (2010:

menyatakan metode penelitian eksperimen dapat diartikan sebagai metode penelitian yan digunakan untuk mencari pengaruh perlakuan tertentu terhadap yang lain dalam kondisi yang terkendalikan. (Sugiyono (2013:3) menyatakan "Metode penelitian adalah cara ilmiah untuk mendapatkan data dengan tujuan dan kegunaan tertentu".

Dapat ditarik kesimpulan metode penelitian, yaitu penelitian merupakan sekumpulan peraturan, kegiatan, dan prosedur. metode yang digunakan dalam penelitian yaitu metode penelitian kuantitatif. metode kuantitatif adalah metode penelitian yang berdasarkan pada filsafat positivisme, digunakan untuk meneliti pada populasi atau sampel tertentu.

Jenis metode dalam penelitian ini adalah eksperimen, yaitu suatu percobaan. Sugiyono (2013:107) menyatakan "metode yang menjadi bagian dari metode kuantitatif'. Bentuk pre-exsperimental designs yang digunakan yaitu: one-group pretestposttest design.

Desain yang digunakan dalam penelitian ini adalah Pre-Experimental 
Designs (Nondesigns). Sugiyono, (2013:109) Pre-Experimental Designs belum merupakan eksperimen sungguhsungguh, karena masih terdapat variabel luar yang ikut berpengaruh terhadap terbentuknya variabel dependen. Jadi hasil eksperimen yang merupakan variabel dependen itu bukan sematamata dipengaruhi oleh variabel independen. Hal ini dapat terjadi, karena tidak adanya variabel kontrol, dan sample tidak dipilih secara random.

Desain ini diberikan pretest terlebih dahulu kepada sampel selanjutnya setelah itu dilanjutkan dengan pemberian perlakuan yang telah ditetapkan dan tahap akhirnya diberikan posttest kepada sampel, pengukuran dilakukan sebelum dan sesudah perlakuan diberikan dan pelaksanaan diukur dari perbedaan antara pengukuran awal $\left(\mathrm{O}_{1}\right)$ dan pengukuran $\operatorname{akhir}\left(\mathrm{O}_{2}\right)$.

\section{$01 \times 02$}

\section{Desain one group pretest posttest} Sumber (Sugiyono 2013:109)

Keterangan :
$\mathrm{O} 1$ = nilai pre-test (sebelum di beri perlakuan)

$\mathrm{X}=$ perlakuan (treament) yaitu menggunakan permainan circuit

$\mathrm{O} 2$ = nilai post-test (setelah diberi perlakuan).

\section{HASIL DAN PEMBAHASAN}

Penelitian ini dilaksanakan pada tanggal 1 november 2019 sampai dengan 15 november 2019. Hasil penelitian: pertama, berdasarkan dari data hasil Pretest dan Posttest SMP Negeri 2 Ella Hilir menunjukan bahwa nilai pretest dan posttest kemampuan lompat jauh gaya jongkok siswa kelas VII SMP Negeri Ella Hilir, untuk hasil pretest nilai minimal $=43,75$ nilai maksimal $=75$ dengan jumlah total $=$ 1.737,5 dan nilai rata-rata $=57,91$. Sedangkan untuk hasil posttest nilai minimal $=68,75$ dan maksimalnya $=$ 93,75 dengan jumlah total $=2.462,5$ dan nilai rata-rata $=82,08$. Nilai pretest dan posttest berdasarkan hasil dari penelitian yang diambil. Pretest (sebelum) dan posttest sesudah diberikan tritmen pada siswa kelas VII SMP Negeri 2 Ella Hilir. Dapat disimpulkan bahwa dari hasil tes pretest dan posttest menujukan adanya peningkatan yaitu sebesar $24,17 \%$ 
berdasarkan KKM dalam penelitian ini tentu sudah memenuhi kriteria keberhasilan.

Kedua, pada pengujian normalitas terdapat nilai tarap signifikansinya yaitu sebesar 0,0200 atau lebih besar dari 0.05 maka hipotesisnya menyatakan bahwa data tersebut terdistribusi normal.

Ketiga, pada pengujian $\mathrm{t}$ tes terdapat nilai Srd. Deviation (deviasi) sebesar $=7,10$, nilai $\mathrm{t}=-18,633, \mathrm{df}=29$ dan nilai Sig. (2-tailed) sebesar $=0,00$. Karena nilai Sig. $(2$-tailed $)=0,00$ atau lebih kecil dari 0,05 yaitu menunjukan adanya perbedaan dan dapat disimpulkan adanya pengaruh setelah diterapkan suatu perlakuan (treatment).

Keempat, pada perhitungan NGain. Berdasarkan hasil perhitungan tabel output N-Gain diatas, menunjukkan bahwa nilai rata-rata $\mathrm{N}$ Gain pada kelas eksperimen diatas adalah sebesar $=58,039$ termasuk dalam kriteria Normalized Gain sedang. Dengan nilai minimum $=28,57$ dan maximum $=85,71$.

Penelitian ini dilaksanakan di SMP Negeri 2 Ella Hilir selama tiga minggu dengan tiga kali pertemuan.
Subjek dalam penelitian ini berjumlah 30 orang. Objek dalam penelitian ini yaitu penerapan model permainan aktivitas circuit terhadap pembelajaran lompat jauh gaya jongkok pada siswa. Pada penelitian ini menggunakan instrumen tes praktek lapangan pretest dan posttest. Untuk mendapatkan instrumen yang baik maka diperlukan pengujian pada instrumen yang akan digunakan. Peneliti terlebih dahulu melakukan validitas instrumen dengan menggunakan validitas konstruk dengan dosen dan guru olahraga sebagai validatornya.

Proses selanjutnya yaitu kegiatan utama dalam penelitian yaitu proses pembelajaran, dalam pertemuan pertama peneliti memberikan penjelasan dan praktek tanpa perlakuan dengan pretest penilaian. Kemudian pertemuan kedua peneliti memberikan perlakuan dengan menggunakan model permainan aktivitas circuit yang terdiri atas empat pos sebagai media praktek lompat jauh gaya jongkok. Selama proses pembelajaran peneliti masih ada menemukan permasalahan yaitu teknikteknik yang masih belum mampu dikuasai oleh siswa dan dengan metode 


\section{Jurnal Pendidikan Jasmani Kesehatan dan Rekreasi (Penjaskesrek) \\ Volume 8, Nomor 1, Januari 2021}

yang diberikan peneliti kepada siswa, perlahan mampu menghadapi kegiatan praktek tersebut. Kemudian pada pertemuan ketiga peneliti memberikan praktek posttest penilaian setelah mendapatkan perlakuan dengan menggunakan model permainan aktivitas circuit hasil belajar siswa pada pembelajaran lompat jauh gaya jongkok dengan metode model permainan aktivitas circuit lebih tinggi dari pada hasil belajar siswa sebelum mendapatkan perlakuan (pretest), dapat dilihat dari nilai rata - rata sesudah diberi perlakuan (posttest) $=82,08$ sedangkan nilai rata-rata sebelum diberi perlakuan $($ pretest $)=57,91$ dengan demikian bahwa terdapat pengaruh dalam model permainan aktivitas circuit terhadap pembelajaran lompat jauh gaya jongkok, jadi dapat disimpulkan bahwa terdapat suatu perbedaan hasil belajar siswa sebelum dan sesudah mendapat perlakuan dengan menggunakan suatu model permaianan aktivitas circuit pada pembelajaran lompat jauh gaya jongkok.

Dalam penelitian ini menggunakan SPSS 25, Pengujian normalitas berdasarkan hasil perhitungan pada tabel 4.2 dapat dilihat pada nilai tarap signifikansinya, yaitu sebesar 0,200 lebih besar dari 0,05 (signifikan > 0,05) maka hipotesis yang menyatakan bahwa data tersebut terdistribusi normal. Kemudian Pengujian hipotesis (perbedaan) berdasarkan hasil perhitungan pada tabel 4.4. paired samples $t$ Test dapat dilihat bahwa nilai Srd. Deviation (deviasi) sebesar $=7,10$, nilai $\mathrm{t}=$ 18,633, df $=29$ dan nilai Sig. (2-tailed) sebesar $=0,00$. Karena nilai Sig. (2-tailed) $=0,00$ atau lebih kecil dari 0,05 yaitu menunjukan adanya perbedaan dan dapat disimpulkan adanya pengaruh setelah diterapkan suatu perlakuan (treatment).

Terakhir dengan Perhitungan NGain, berdasarkan hasil perhitungan tabel 4.6. Output pengujian N-Gain Descriptives menunjukkan bahwa nilai rata-rata $\mathrm{N}$-Gain pada kelas eksperimen adalah sebesar $=58,039$ dapat disimpulkan berdasarkan hasil perhitungan tesebut termasuk dalam kriteria Normalized Gain sedang. Dengan nilai minimum $=28,57$ dan maximum $=85,71$.

\section{KESIMPULAN}


Berdasarkan hasil analisis dapat disimpulkan sebagai berikut:

1. Rata-rat hasil belajar siswa sebelum penerapan aktivitas circuit pada pembelajaran lompat jauh gaya jongkok dengan jumlah siswa 30 orang memperoleh hasil 57,91.

2. Rata- rata hasil belajar siswa setelah dilakukan penerapan aktivitas circuit pada pembelajaran lompat jauh gaya jongkok dengan jumlah siswa 30 orang memperoleh hasil 82,08 .

3. Berdasarkan uji hipotesis hasil output uji paired samples t test pada saat kegiatan praktek sebelum dan sesudah diberi perlakuan karena nilai Sig (2-tailed) sebesar $=0,00$ atau lebih kecil dari 0,05 dapat disimpulkan bahwa adanya perbedaan antara sebelum dan sesudah diberikan perlakuan. Dengan demikian penerapan model permainan aktivitas circuit terbukti efektif digunakan dalam

pembelajaran lompat jauh gaya jongkok pada siswa kelas VII di SMP Negeri 2 Ella Hilir.

4. Berdasarkan hasil output pengujian $N$-Gain menunjukan bahwa nilai rata-rata pada kelas eksperimen sebesar = 58,039 yaitu dapat disimpulkan bahwa data tersebut termasuk dalam kriteria Normalized Gain sedang.

\section{DAFTAR PUSTAKA}

Aminuddin. 2010. Pengantar Apresiasi Sastra. Bandung: Sinar Baru Algendindo.

Djumidar. 2007. Gerak-gerak Dasar Atletik. Jakarta: Pusat Penelitian Universitas Terbuka Sugiyono. 2013. Metodologi Penelitian Pendidikan Pendekatan Kuantitatif, Kualitatif, dan $R \& D$. Bandung: Alfabeta. 